\title{
ПРИНЦИПИТАМЕТОДИМОТИВАЦЇПРАЦІВНИКІВТУРИСТИЧНОГОПІДПРИЕМСТВА
}

Анотація. Розглянуто сутність поняття «мотивація». Це сукупність зовнішніх і внутрішніх чинників, які спонукають людину виконувати поставлені завдання, що приводить до досягнення цілей працівника та організащії загалом. Наведено класифікацію мотивації за різними ознаками. Висвітлено принщипи мотивування працівників туристичних підприемств. Для мотивації персоналу слід поєднувати методи матеріального так і нематеріального стимулювання. Найбільш дієва матеріальна мотивація, основними елементами якої є оплата праці та надбавки. Проте їі необхідно поєднувати з нематеріальною мотивацією, яка включає похвалу працівника, привітання з урочистими подіями, влаштування корпоративних свят, можливість кар'єрного росту, доручення цікавої роботи тощо. Розкрито основні методи мотивування працівників.

Ключові слова: мотивація, персонал, методи, матеріальне стимулювання, нематеріальне стимулювання.

Terebukh Andrii, Ilnytska-Hykavchuk Halyna National University «Lviv Polytechnic»

\section{PRINCIPLES AND METHODS OF MOTIVATION OF EMPLOYEES OF THE TOURIST ENTERPRISE}

Summary. The essence of the concept of «motivation» is considered. This is a set of external and internal factors that encourage a person to perform the tasks that lead to the achievement of the goals of the worker and the organization as a whole. The classification of motivation according to different characteristics is given: according to groups of needs (material, labor, status), according to the used methods (normative, compulsory, stimulating), by sources of origin (internal, external), in the direction of achieving the goal (positive, negative). An effective motivation system for tourism enterprises should be based on the following principles: continuity of motivation process; a combination of material and non-material methods of motivating staff; motivation efficiency; comprehensiveness of motivation; conformity. Material motivation is divided into two types: material monetary and material non-monetary motivation. The methods of material monetary incentives include: wages, bonuses and allowances, commission fees, tuition fees and staff qualification upgrades. The forms of material non-monetary motivation include: benefits when using social institutions of the organization; nutrition of the personnel; use of official car and phone; increase of technical equipment and comfort of the workplace; providing tickets for visiting various cultural events and more. In the field of tourism, such methods of motivation as trip of employees in tourist trips can also be used. Intangible motivation includes praise of the employee, greetings with solemn events, arrangement of corporate holidays, the possibility of career growth, the assignment of interesting work, etc. To achieve the best result it is necessary to combine different methods of motivation.

Keywords: motivation, personnel, methods, material incentives, non-material incentives.

$\Pi^{2}$ остановка проблеми. Мотивація персоналу є надзвичайно актуальною і важливою проблемою, оскільки від неї залежить успіх діяльності підприемства, рівень добробуту колективу. Ефективне управління персоналом вимагає чіткого усвідомлення мотивів і потреб людини, а також уміння правильно стимулювати персонал до праці. Вибір найбільш ефективних методів мотивації є важливим завданням керівного персоналу кожного підприемства.

Аналіз останніх досліджень і публікацій. Проблеми мотиващії праці персоналу досліджували такі вчені як Балабанова Л.В., Вербицька Г.Л., Калініченко Л.Л., Кіптенко В.К., Колот А.М., Цимбалюк С.О., Макклелланд Д., Маслоу А., Олійник С.У., Устіловська А.С., Херцберг Ф., Крушельнищњка О.В., Климчук А.О. та багато інших.

Мета статті. Метою статті є висвітлення сутності, принципів і методів мотивації персоналу туристичних підприемств.

Виклад основного матеріалу. В економічній літературі термін «мотивація» трактуеться по-різному. Так, Мескон М. визначае мотивацію як процес спонукання себе та інших до діяльності для досягнення особистих цілей і цілей організації [1]. На думку Гріфріна Р. та Яцури В., це сукупність чинників, які зумовлюють поведінку людей [2]. Згідно Колот А.М., мотиващія - це сукупність внутрішніх і зовнішніх рушійних сил, які спонукають людину до діяльності, визначають поведінку, форми діяльності, надають цій діяльності спрямованості, орієнтованої на досягнення особистих цілей і цілей організації [3]. Це внутрішній процес свідомого вибору людиною того чи іншого типу поведінки, що визначається комплексним впливом зовнішніх (стимули) i внутрішніх (мотиви) чинників [4]. Узагальнюючи дані визначення, слід зазначити, що мотивація, по-перше, це сукупність зовнішніх i внутрішніх чинників, по-друге, дія їх спонукає людину виконувати поставлені завдання, обирати певний тип поведінки, по-трете, така діяльність людини сприяе досягненню її цілей та цілей організації.

Мотивацію можна класифрікувати за різними ознаками (рис. 1).

Залежно від потреб розрізняють такі види мотивації [5; 6]: матеріальну, трудову, статусну. Першим стимулом до праці є матеріальна зацікавленість, тобто отримання матеріальної винагороди, яка може бути виражена в грошовому вимірнику, матеріальних об'єктах або послугах [7].

Найбільш дієва матеріальна мотивація, проте використання тільки її приводить до виснажен- 


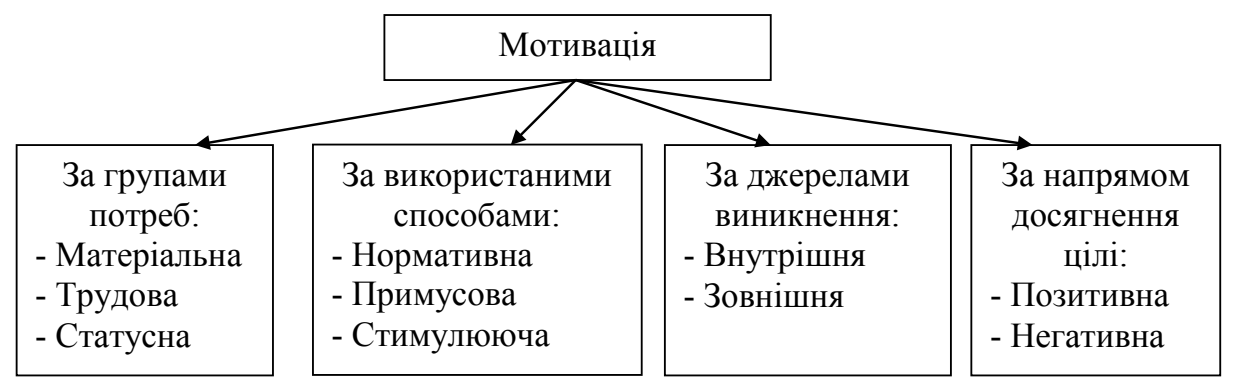

Рис. 1. Класифікація мотивації

Джерело: розробка автора за джерелами [5; 6; 7]

ня пращівників, їх нервового перевантаження. Тому доцільно їі поєднувати 3 трудовою мотивацією, яка породжуеться самою роботою, її змістом, умовами, режимом праці, організацією трудового процесу тощо.

Це внутрішня мотивація пращі, в якій пріоритетними $е$ внутрішні мотиви (суть пращі, відповідальність, успіх) перед зовнішніми (відносини 3 колегами, заробітна плата тощо). Для підвищення трудової мотивації доцільно давати працівникам цікавішу роботу, ставити нові завдання 3 творчим характером; має бути можливість підвищення професійності працівників; робітник повинен відчувати свою потребу; спільне прийняття рішень; надавати працівникові самостійність в прийнятті рішень; створення сприятливого клімату в колективі [8].

Статусні мотиви є внутрішньою рушійною силою поведінки, пов'язаної з прагненням людини посісти вищу посаду, виконувати складнішу, відповідальнішу роботу, працювати у сорері діяльності (організації), яка вважається престижною, суспільно значущою. На думку Крушельнищької O.В., є такі прийоми статусної мотивації [8]: підвищення на посаді; винагороди і визнання досягнень; залучення людей до управління; заохочення і винагороди групової роботи.

Нормативна мотивація - передбачає спонукання людини до поведінки за допомогою психологічного впливу: навіювання, переконання, інформування тощо. На застосуванні влади, погрозах до працівника у випадку невиконання ним вимог базується примусова мотивація.

Стимулююча мотивація - це вплив на особистість, щоб вона сама захотіла якісно виконувати на неї покладені обов'язки.

За джерелами виникнення мотивів виділяють мотивацію внутрішню і зовнішню. Внутрішня мотивація - це коли людина сама форомує мотиви. Наприклад, прагне досягнути певної мети, завершити роботу тощо. На основі внутрішньої мотивації люди відповідальніше виконують роботу, менше затрачають сил, краще розуміють завдання. I навпаки, зовнішня мотивація передбачає вплив на суб'єкт ззовні, наприклад, через заробітну плату, штрафи, накази тощо. Проте в різних ситуащіях мотиви можуть виникати по внутрішніх та по зовнішніх причинах.

За напрямом досягнення цілей розрізняють мотивацію позитивну та негативну. В свою чергу, позитивна сприяе досягненню цілей і включає матеріальне заохочення у вигляді доплат до заробітної плати, премії, доручення особливо важливої роботи для працівника, похвала тощо. Негативно мотивують людей штрафи, пониження по посаді, психологічний дискомфорт.

Дієва система мотивування працівників туристичних підприемств повинна базуватися на таких принципах:

- безперервність процесу мотивування - мотивування працівників має постійно проводитися для того щоб вони ефективно працювали;

- поєднання матеріальних та нематеріальних методів мотивування персоналу;

- ефрективність мотивування - система мотивування має приносити очікувані результати, в протилежному випадку вона $є$ неефективною і має бути заміненою;

- всеохоплюваність мотивування - мотивування має стосуватися всього персоналу;

- відповідність - система мотивування має відповідати результатам праці працівника.

Для мотивації персоналу слід поєднувати методи як матеріального стимулювання так і нематеріального (рис. 2).

Матеріальна мотиващія буває двох видів - матеріальна грошова та матеріальна негрошова мотивація.

До методів матеріального грошового стимулювання Колот А.М. відносить [3]:

1. Заробітна плата, рівень якої визначае можливості відтворення робочої сили, а тому й мотивацію.

2. Премії за виконання поставлених завдань (підвищення якості послуг, виконання плану продажів, підвищення ефрективності обслуговування, розширення клієнтської бази тощо).

3. Оплата за навчання працівників на курсах, тренінгах, в навчальних закладах.

4. Медичне обслуговування.

5. Страхування.

Актуальними є такі методи грошової матеріальної мотивації [10]:

- доплати до основної заробітної плати за володіння певними навичками та вміннями (знання іноземних мов, користування комп'ютерними програмами);

- оплачуване тимчасове звільнення від роботи (святкування днів народження, шлюб, похорони);

- оплата і надання навчальних відпусток;

- грошові нагороди та виплати у зв'язку 3 днем народження, смертю родичів.

До фором матеріальної негрошової мотивації можна віднести: скорочений робочий день; гнучкий графік роботи; пільги при користуванні соці- 


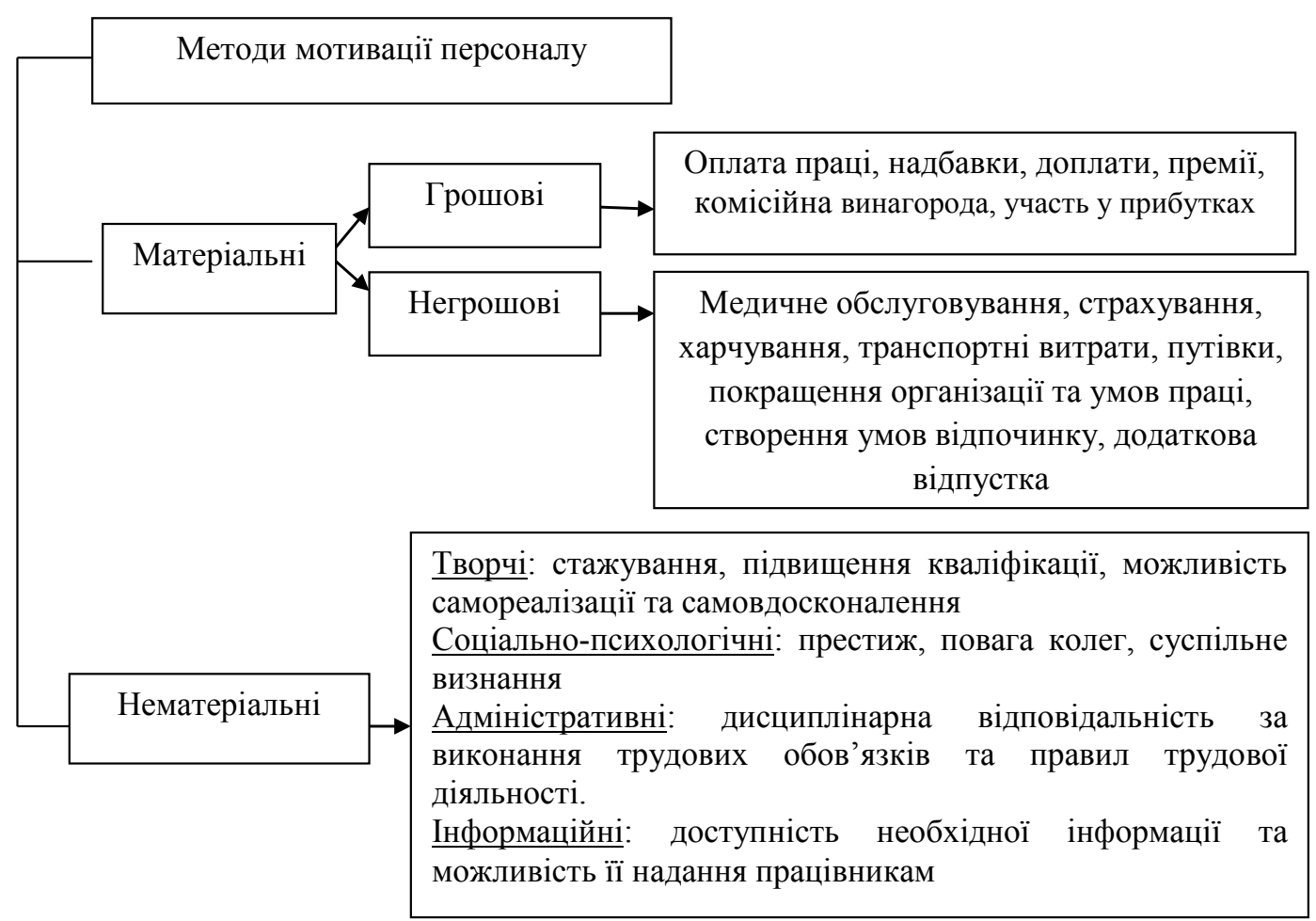

Рис. 2. Класифікація методів мотивації персоналу

Джерело: розробка автора за джерелом [9]

альними установами організащії; користування службовим автомобілем та телефоном; підвищення технічної оснащеності і комфортності робочого місця; надання квитків на відвідини різних культурних заходів [10].

Ефективним способом мотиващї працівників є соціальний пакет. Він включає підвищення кваліфікації або навчання за рахунок фрірми, організацію безкоштовного харчування, оплату транспорту і зв'язку, пільгові путівки в санаторій за станом здоров'я.

В сорері туризму використовуються також такі методи мотивування як відрядження працівників в тури, під час яких вони ознайомлюються з певними рекреаційними територіями, закладами розміщення, харчування тощо. Такі тури можуть повністю оплачуватися за рахунок фірми. Для стимулювання персоналу туристичних підприемств доцільно надавати також знижки на тури для сім'ї працівника.

До методів матеріальної негрошової мотивації відноситься також створення оптимальних умов праці: хороший дизайн приміщення, установка сучасного комп'ютерного обладнання, сучасні системи опалення, кондиціонування.

У зміст нематеріального стимулювання персоналу повинні бути закладені концепцї підвищення якості трудового життя, співучасті працівників у розподіленні прибутків, планування кар'єри, інформованість персоналу. Такі складові нематеріального стимулювання забезпечують подолання відчуття напруженості в колективі, зневіри, гніву тощо.

Метою нематеріальної мотивації $є$ підвищення зацікавленості працівника до справи на благо організації. Одним із способів нематеріальної мотивації є участь у спільних корпора- тивних заходах, які сприяють створенню здорової атмосфери у колективі. Розрізняють адресні та безадресні методи нематеріальної мотивації. Прикладом адресної нематеріальної мотивації $\epsilon$ привітання працівника із іменинами, днем народження, похвала 3 боку керівника. Безадресна мотивація полягає у проведенні спільних корпоративних заходів, надання різних пільг та ін. Одним із найважливіших методів нематеріальної мотивації є влаштування корпоративних свят.

До методів нематеріальної мотивації також відносять: можливості кар'єрного росту персоналу; доручення працівникові цікавої роботи, яка приносить йому задоволення; створення сприятливого для роботи психологічного клімату в колективі; спільне прийняття рішень; надання працівникові свободи та самостійності при виконанні завдань; інформування керівником персоналу про справи підприемства, плани та перспективи [8].

Всі перелічені методи мотиващії є ефрективними та достатньо дієвими, але керівник повинен використовувати певний метод залежно від ситуащії. Для досягнення найкращого результату необхідно комбінувати різні методи мотиващії.

Висновки. Отже, мотивація є важливим завданням кожного підприемства, оскільки від ефрективної праці персоналу залежать результати діяльності підприемств. Особливо це стосуеться сорери послуг та туристичних підприемств, де на якість послуг значною мірою впливає обслуговуючий персонал. Мотивація повинна базуватися на певних принципах. Для ефрективної побудови системи мотивації необхідно поєднувати методи як матеріальної, так і нематеріальної мотивації. 


\section{Список літератури:}

1. Мескон М.Х., Альберт М., Хедоури Ф. Основы менеджмента. Москва : Дело, 1998. 704 с.

2. Гріфін Р., Яцура В. Основи менеджменту : підручник. Львів : БаК, 2001. 624 с.

3. Колот А.М., Цимбалюк С.О. Мотивація персоналу : підручник. Київ : КНЕУ, 2011. 397 с.

4. Кибанова А.Я. Управление персоналом организации : учебник. Москва : ИНФРАМ, 2005. 638 с.

5. Вербицька Г.Л. Мотивування персоналу на вітчизняних промислових підприємствах. Вісник Національного університету «Львівська політехніка». 2012. № 727. С. 10-15.

6. Гайдученко С.О. Мотивація персоналу. Харків : ХНУМГ ім. О.М. Бекетова, 2013. 111 с.

7. Устіловська А.С. Мотивація персоналу як один з основних інструментів успішного управління персоналом. Молодий вчений. 2017. № 4.4(44.4). С. 112-115.

8. Крушельницька О.В., Мельничук Д.П. Управління персоналом : навч. посібник. Київ : Кондор, 2003.296 с.

9. Климчук А.О., Михайлов А.М. Мотивація та стимулювання персоналу в ефективному управлінні підприемством та підвищенні інноваційної діяльності. Маркетинг і менеджлент інновацій. 2018. № 1. С. $218-234$.

10. Дідур К.М. Сутність мотивації праці та методи їі оцінки. Агросвіm. 2011. № 11. URL: http://www.agrosvit.info/ pdf/11_2011/9.pdf

\section{References:}

1. Meskon M.H., Al'bert M., Hedouri F. (1998). Osnovy menedzhmenta [Fundamentals of Management]. Moskva : Delo. (in Russian)

2. Hrifin R., Yatsura V. (2001.) Osnovy menedzhmentu [Fundamentals of Management]. Lviv : BaK. (in Ukrainian)

3. Kolot A.M., Tsymbaliuk S.O. (2011). Motyvatsiia personalu [Motivation of the personnel]. Kyiv : KNEU. (in Ukrainian)

4. Kibanova. A.Ya. (2005). Upravlenie personalom organizacii [Organization Personnel Management]. Moskva : INFRAM. (in Russian)

5. Verbytska H.L. (2012). Motyvuvannia personalu na vitchyznianykh promyslovykh pidpryiemstvakh. [Motivation of personnel at domestic industrial enterprises]. Visnyk Natsionalnoho universytetu "Lvivska politekhnika", no. 727 , pp. $10-15$.

6. Haiduchenko S.O. (2013). Motyvatsiia personalu [Motivation of the personnel]. Kharkiv : KhNUMH im. O.M. Beketova. (in Ukrainian)

7. Ustilovska A.S (2017). Motyvatsiia personalu yak odyn z osnovnykh instrumentiv uspishnoho upravlinnia personalom [Motivation of staff as one of the main tools for successful personnel management]. Molodyi vchenyi, no. 4.4(44.4), pp. 112-115.

8. Krushelnytska O.V., Melnychuk D.P. (2003). Upravlinnia personalom [Personnel Management]. Kyiv : Kondor. (in Ukrainian)

9. Klymchuk A.O., Mykhailov A.M. (2018). Motyvatsiia ta stymuliuvannia personalu v efektyvnomu upravlinni pidpryiemstvom ta pidvyshchenni innovatsiinoi diialnosti [Motivation and stimulation of personnel in effective management of the enterprise and increase of innovative activity]. Marketynh $i$ menedzhment innovatsii, no. 1, pp. 218-234.

10. Didur K.M. (2011). Sutnist motyvatsii pratsi ta metody yii otsinky [The essence of the motivation of labor and methods for its evaluation]. Ahrosvit, no. 11. Available at: http://www.agrosvit.info/pdf/11_2011/9.pdf 